\title{
THREE WAYS OF GOING WRONG: KIPLING, CONRAD, COETZEE
}

It begins with a fall. A man stumbles at the threshold of a dark alley, deep in the native quarter of a colonial Indian city. This is Trejago, on his late-night and secret wanderings in search of knowledge, romance and adventure, in Kipling's story 'Beyond the Pale', published in 1888 in Plain Tales from the Hills. ${ }^{1}$ He presses on into the alley, Amir Nath's Gully, where he will meet and begin a dangerous affair with Bisesa, a fifteen-year-old widow immured in the house of her uncle, whose eventual discovery of the affair precipitates violence and tragedy: Bisesa's hands are cut off, Trejago is wounded in the groin but escapes with his life (though he loses his reason, at least for a while, and probably his manhood), and in the end he returns to the law-abiding and colourless world of colonial respectability, from which he will never venture again. The embarrassing lapse passes, for him, without scandal, and his career and reputation are intact. He has gone wrong; but before it was absolutely too late, he has - in the evangelical phrase - got right, and taken refuge within the pale of the law.

The phrase 'beyond the pale' goes back to the very earliest geography of English or actually Angevin colonialism, when in the fourteenth century the Irish Pale enclosed a felicitous space of English law and order, while lawlessness and savagery held sway beyond the pale. Trejago in Kipling's tale has not broken the colonial law, strictly speaking, but he has 'wilfully stepped beyond the safe limits of decent everyday society'; his stumbling transgression is a sexual one, but it is also epistemelogical and anthropological . 'He knew too much in the first place, and he saw too much in the second. He took too deep an interest in native life; but he will never do so again.' (PT, p. 162) Trejago has an expertise and a curiosity about Indian life which is both his password to forbidden pleasures, and the crime for which he will pay. After their first encounter in the dark, in which they exchange whispered quotations for 'The Love Song of Har Dyal', Bisesa the next day makes an assignation with Trejago by means of an object-letter tossed into his dogcart as he drives to his office. The object-letter - containing no verbal message, but half of a broken glass bangle, one dhak flower, a pinch of cattle-food and eleven cardomoms - is both an invitation and a kind of examination for Trejago; decoding it successfully allows him to graduate to Bisesa's chamber and its delights. Trejago embarks on a double life, the respectable colonial in his office by day, but the lover of Bisesa in the dark. But transgressors always have to pay, at least in Kipling, and in the colonial imagination a surrender to oriental temptations is often the path to insanity or inanition. Trejago's penetration into the closed oriental world leads to a terrible moment of violence, the mutilation of Bisesa and the attack on her lover that leaves him 'raging and shouting like a madman between those pitiless walls'. (PT, p. 167)

Trejago's madness, in both senses, is temporary. Having lost Bisesa, he returns to his own kind, and the daylight world of law-abiding respectability, passionless regularity and cynical lies - like the one with which the narrator concludes the story: 'There is nothing peculiar about him [Trejago], except a slight stiffness, caused by a riding-strain, in the right leg’ ( $P T$, p. 167) In a sense, Trejago's return to respectability can be historicized. Ronald Hyman estimates that ninety per cent of the British in India in the mid-eighteenth century made marriages with local women, the bibis whose mixed sexual and educational attractions are memorialized in the slang term, sleeping dictionary. Missionary disapproval, the professionalizing of the service, and the racial anxiety that spread across the empire from anti-white riots in the West Indies, brought about a change in attitude, and what Hyman calls 'the double advent of the Mutiny and the Memsahib' drove the Indian mistress out of the colonial house in the 1860s. ${ }^{2}$ Trejago has to keep Bisesa secret, and the eventual disaster appears to convince him to keep to his side of the fence from now on, and cease to take 'too deep an interest in native life'. (162) There we can leave him, 
damaged but not quite sunk after his encounter with the siren of native ways, but noting that Trejago is not just a philanderer but an orientalist. The narrative is not being euphemistically coy when it says that Trejago 'knew too much' and 'saw too much'. He wants to know Bisesa, not just to enjoy her. His siren promises knowledge, like the ones who sang to Odysseus that they knew all the matter of Troy.

The final story in Plain Tales from the Hills also starts with a fall, in the dark. In 'To be filed for reference', the narrator literally picks up a drunken Englishman who has stumbled over a camel-colt in the Serai, and thus enters the world of McIntosh Jellaludin, loafer, scholar and fallen gentleman, who has gone wrong in a more uncompromising and permanent way than Trejago. McIntosh, who lives in abject poverty with a 'native woman', has become a Muslim fakir. 'When a man begins to sink in India, and is not sent Home by his friends as soon as may be, he falls very low from a respectable point of view. By the time that he changes his creed, as did McIntosh, he is past redemption.' (PT, p. 271) McIntosh has gone over permanently into the dark world which Trejago visited as a sex tourist, and he has adopted its customs, language, religion, and diet, and married - it is a marriage - a local woman. So alarming and enticing are these transgressions that the narrator who befriends him has to keep McIntosh as much a secret as Trejago kept Bisesa. 'Unluckily, one cannot visit a loafer in the Serai by day. Friends buying horses would not understand it. Consequently, I was obliged to see McIntosh after dark.' (PT, p. 272) As these visits develop into a kind of friendship, a rather fastidious point is made of the abject squalor of the McIntosh household. McIntosh drinks 'filthy country-liquors', lives 'down here in the garbage', and gets 'loathsomely drunk'. (PT, pp. 272, 274)

But the first thing that strikes the narrator (whom I am very tempted to call Kipling) is that McIntosh is a cultured and learned man. He falls over the camel while quoting D. G. Rossetti. He likens himself to Ovid in exile or Dante in the underworld. Far gone in drink, he imagines himself back among Oxford places, whose names the narrator rather proudly recognizes, and claims once to have been a Fellow of a College. Classicist and modernist, he quotes Swinburne and Browning, but does most of his drunken ravings in Greek or German. If all Europe has contributed to the making of McIntosh, the focus of his learning is now India. For at the cost of his respectability, his comfort, his health, his name (in both senses) and shortly of his life, McIntosh has acquired a knowledge of the native world unrivalled among his kind. He really does, the narrator acknowledges, have 'his hand on the pulse of native life', (PT, p. 275) boasting an expertise which eclipses even that of Strickland, the policeman with a taste for what he calls shikar or hunting in disguise among the native crowd, who appears to the slavish admiration of other early stories. McIntosh 'used actually to laugh at Strickland as an ignorant man - "ignorant West and East” - he said.' (PT, p. 275) But McIntosh’s knowledge has been purchased dearly, in his social death to colonial society, the degradation of his domestic amenities, the debilitation of his alcoholism, and the certainty of his approaching death. He is, in his own eyes, a scholar who has made a Faustian bargain. Before he dies, he bequeaths to the narrator a big bundle of papers, the Book in which all this knowledge of Indian life is contained.

'This,' he said, 'is my work - the Book of McIntosh Jellaludin, showing what he saw and how he lived, and what befell him and others; being also an account of the life and sins and death of Mother Maturin....' (PT, p. 276)

The narrator is enjoined to adopt the Book (which McIntosh calls 'my only baby') and not to let it die; the book will make him famous. 'It is a great work, and I have paid for it in seven years' damnation.' (PT, p. 277) With this deathbed legacy, the narrator is appointed guardian of the hybrid offspring of McIntosh's transgressive researches in native life - 'the lost gospel of British 
India', as Gail Ching-liang Low calls it. ${ }^{3}$ At this time, of course, Kipling was still working on his ambitious novel, unpublished and now lost, about the horrors of Eurasian and native life, which was to be called Mother Maturin. In this context, the tale 'To be filed for reference' is both a sort of advertisement for that book, a deferral of it, and a sort of fantasy prophylactic against the kind of adverse criticism which its reception by his family had perhaps already led him to anticipate. ${ }^{4}$ 'If the thing is ever published, some one may perhaps remember this story, now printed as a safeguard to prove that McIntosh Jellaludin and not I myself wrote the Book of Mother Maturin.' (PT, p. 277)

Interesting though the tale is for the light that it sheds on Kipling's relation to his own writing, it is its representation of the man gone wrong that is to my purpose at the moment, for the man who goes wrong is a figure of fascination and anxiety in colonial discourse, a fascination and an anxiety embodied in the other man, who stands as his witness. At the centre of this tale, then, is not the figure of McIntosh himself, but rather the relationship between him and the narrator who becomes, in an unexpected way, his friend and later his heir. The narrator himself comes from the daylight world of colonial work and respectability. Law-abiding himself, he is enthralled by the transgressor, forming but at the same time denying a misgiving bond with him, listening to his voice and learning from him - in exchange for tobacco, McIntosh taught him 'several ounces of things worth knowing' (PT, p. 275) - becoming something like his student, inheritor and transmitter of what the transgressor has learned; but in another sense the law-abiding witness is the outlaw's complement or even opposite. The transgressor has given in to Faustian temptation, and he may become in turn the temptation of the lawman, but it is a temptation the lawman resists, withdrawing within the saving boundary of the law. The relationship in 'To be filed for reference' is ambiguous, as the narrator pities, patronises, admires, mocks, likes, and disapproves of McIntosh, and is left with the problem of how to execute his memory.

And as a matter of fact we have seen this kind of relationship before, in the case of 'Beyond the Pale'. The narrator in the earlier story is not a dramatized character, but he is drawn to Trejago and his story while disapproving and warning against it, just as the other narrator is drawn to McIntosh. The 'Beyond the Pale' narrator distances himself from Trejago, telling the story of his misfortune as a cautionary tale, warning against the mistakes Trejago made; and yet he is closer to Trejago than he will admit, his discourse shows him to be as familiar as Trejago was with the forbidden corners of the native city and the esoteric language of object letters. 'No Englishman should be able to translate object-letters,' he warns gravely, and proceeds to offer both translation and commentary. (PT, p. 163) This cautionary tale about the dangers of native women dwells more lovingly than might be considered necessary on the delights of Bisesa's body and company. Though this narrator has the familiar Kipling aloofness, it is a knowing aloofness, and he could not tell Trejago's story if he had no knowledge of the secret places where Trejago has been.

I suggest that we have a myth of colonial discourse in this pattern: not in the figure of the man gone wrong, but in the relationship between him and the other, the outlaw and the lawman. 'Beyond the Pale' gives a partial, and 'To be filed for reference' a full version of Kipling's rendering of this myth, which goes like this. These two recognise each other and a bond is formed, reluctantly on both sides, between them. They discourse together. The transgressor has given in to temptation; he may indeed become in turn the temptation of the straight man, a temptation resisted perhaps with difficulty. A transaction takes place, whereby the lawman becomes the bearer of the other's knowledge. And finally the lawman is faced with the obligation to bear witness to what he has seen or heard. These two are a dialectical pair, each embodying a necessary aspect of the business of the colonial traffic with its native other. One immerses himself (it is a masculine function) acquisitively in the life and affairs of the native. The other cautiously 
protects himself from its contamination. But they go together; they need each other. Without the lawman, the outlaw may be simply engulfed, disappearing into the overwhelming tide of otherness that always threatens the colonial project: the lawman invokes a kinship to remind him who he 'really' is. But without the outlaw, the lawman may remain fruitlessly aloof, unable to engage with the native in any profitable way. The relationship is one of the allegories of empire. The imperial project can come to nothing unless contact is made with the native, but contact is felt to risk disaster, loss of identity, even forfeit of the soul. And so they go on together, the lawman and the outlaw.

Trejago came to his senses. McIntosh was beyond redemption. Conrad's Mr Kurtz, too, is a man who seems to have gone wrong by going too far. To read Heart of Darkness through the lens of these earlier Kipling tales yields up a familiar story. A gifted man, a man of authority and prestige among his own people, passes beyond the bounds of what is considered acceptable and civilized. The initial contrast here is with the other Europeans in central Africa, whom Kurtz literally leaves behind, the manager and the brickmaker and the pompous and ineffectual company men and 'pilgrims' who have come to Africa to turn a profit but, unlike Kurtz, do not have courage equal to desire. These mediocre Fausts are in thrall to 'a flabby, pretending, weakeyed devil', and are law-abiding only through timidity, laziness and ineffectuality - like Kayerts and Carlier in 'An Outpost of Progress' before opportunity is dumped on their doorstep - and they can only envy and resent the fabulous profits returned from Kurtz's deep transgression into darkness' heart. Kurtz is a scholar, an artist, a writer, a linguist, a man of eloquence and high ideals. He is - again like McIntosh, and like Coetzee's magistrate - an explorer and collector. He comes to Africa as the torchbearer of modernity and progress, a liberal imperialist apparently despatched by the 'gang of virtue' at home, who lectures his less high-minded colleagues on the need to treat the natives well, and on their responsibility and opportunity for 'humanizing, improving, instructing'. (HD, p. 91 $)^{5}$ It is these essentially liberal motives that propel Kurtz into the interior where his own weaknesses are terribly exposed, and it all goes wrong. His desire to protect and to collect turns into a mania to dominate and ransack. Leaving too far behind the safety of numbers and mediocrity, he becomes a freelance predator driven mad by solitude, and forfeits his soul - this is how Marlow will see it - for the satisfaction of his boundless greed. It is essentially a simple story. Beyond the pale Kurtz too has acquired a lover, but this is not the statuesque figure who comes to the river bank to see him depart, but the wilderness itself. 'The wilderness ... had caressed him, and - lo! - he had withered; it had taken him, loved him, embraced him, got into his veins, consumed his flesh, and sealed his soul to its own by the inconceivable ceremonies of some devilish initiation. He was its spoiled and pampered favourite.' ( $H D$, p. 115) It is the wilderness which is Kurtz's 'sleeping dictionary'; it has something to say to him and it says it, whispering to him 'things about himself which he did not know, things of which he had no conception till he took counsel with this great solitude'. (HD, p. 131) It is the siren that lures him to his own wreck. Surrendering to its blandishments, Kurtz like Odysseus loses touch with his best rational intentions and his earlier self, tending, as the Russian reports, to 'forget himself among these people - forget himself - you know'; and indeed Marlow does seem to know, for his immediate diagnosis is 'Why! He's mad'. (HD, p. 129) It is not just a loss of prudence and restraint. Passing beyond the pale takes Kurtz beyond good and evil. 'I am as the Gods, knowing good and evil, but untouched by either.' (PT, p. 274) That was McIntosh in his delirium, but it might as well be Kurtz in his, for both win a temporary sense of omnipotence in a Faustian compact, and both are headed for a fall, acquiring a real or imaginary knowledge/power which is fatal to both of them.

Marlow plays the role of the prosaic, pedestrian reporter of this catastrophe, and his similarities to the two Kipling narrators are enough to suggest that a similar pattern is being played out. His first words about Kurtz describe him as a 'poor chap', (HD, p. 51) but he is soon 
(and long before he meets him) drawn into a sort of bond with Kurtz which belies Marlow's general self-protective and cynical aloofness in relation to what he sees in Africa. He develops a curiosity about Kurtz and even finds himself drawn into the role of Kurtz's partisan and fellowconspirator, as if he really were on Kurtz's side as his enemies in the company believe. Marlow too has been drawn to the dark places, he too admits his kinship with the 'wild and passionate uproar' of African life, (HD, p. 96) and he too despises his fellow-Europeans as Kurtz does. The misgiving recognition of some kind of affinity between the two is something that takes place, in this story, before they meet. It survives the arrogance and the madness of Kurtz's actual words and behaviour towards Marlow, as it belies Marlow's unconvincing insistence on his own detachment: 'Oh, I wasn't touched. I was fascinated'. (HD, p. 149) For in effect Marlow becomes his partner, heir and executor. The man whom he has always imagined as discoursing leaves him a legacy of discourse - a reputation, a bundle of papers, and a deathbed pronouncement. Marlow returns to Europe a haunted man, with a responsibility to Kurtz which he tries (and arguably fails) to discharge with his disposal of the documents, his interview with the Intended, and then with his narration. A compelling if unwelcome bond has been formed, or recognised, between the radically transgressive Kurtz and the scrupulous, restrained and law-abiding Marlow.

Just what has happened to Mr Kurtz? One answer might be given in terms of the possibility of regression, in which the Victorians believed as fervently as they believed in progress, and John W. Griffith has suggested that Victorian readers could well have read Conrad's early fiction 'as stories of the degenerative impact of denationalization - of being cut off from one's culture'. ${ }^{6}$ A hostile climate was thought to put Europeans at risk of this baleful effect, but it could also be the result of mixing with 'primitive' peoples, and Griffith sketches a dilemma facing Conrad's people which is close to the dilemma I have found dramatised in the relationship between lawman and outlaw in the Kipling tales. 'The colonists apparently have only two bleak choices in Conrad's view: to maintain their isolation from the indigenous culture and thus live as permanent outsiders, professional strangers in these "primitive" cultures; or to choose the path of assimilation that for the Victorians was almost synonymous with degeneracy and demoralization. ${ }^{7}$

John A. McClure, however, who wants to acquit Conrad of the charge of viewing the native people of Africa as savage, stresses that Marlow has surprisingly little recourse to stereotypes of infection and degeneration and their readily available vocabulary, and that he emphasises that Kurtz has brought his own greed and ruthlessness with him from Europe. ${ }^{8}$ Whatever the roots of Kurtz's 'savagery', there is no doubt that he is regarded by his fellowEuropeans, including Marlow, as a man who has gone too far, and far beyond what is lawful, in 'going native' to the extent of living and preferring to live among Africans, and taking part - to say the least - in their culture and rites. But it is just this unlawful penetration into native culture that, viewed as a business strategy (albeit one with unsound methods, and disastrous in the longer term), has enabled Kurtz to reap such a spectacular profit from Africa, unlike the sterile antics of the small-minded and ineffectual company men downriver, who seem to be able to produce nothing but holes, and whose curiosity about the native people is confined to the question of how many they can shoot.

Kurtz has actually made contact, though this has made him vulnerable to terrible dangers, including the temptations of knowledge and power that lead to his corruption and self-betrayal. The company depends on people like Kurtz, and will profit in an unambiguous way from his unsound methods, though he will be reported and denounced to his superiors. No profit without knowledge, no knowledge without contact, no contact without transgression. And Marlow, whose interests are less material, takes from Kurtz's hands, or from his discoursing, his own booty from Africa: a word, horror, and a story to tell. 'He won't be forgotten. Whatever he was, he was not 
common,' Marlow tells his listeners. (HD, p. 119) And perhaps the outlaw's transvaluation of values may also help the lawman to clarify his own moral economics, for Marlow adds scrupulously: 'No; I can't forget him, though I am not prepared to affirm the fellow was exactly worth the life we lost in getting him.' This is a reminder that Marlow has already made a contact of his own, and already attended a death, before he sets eyes on Kurtz, a death that he describes and remembers in language of the Marlovian sublime close to the language he uses for Kurtz in extremis: the 'intimate profundity' of the helmsman's dying look 'remains to this day in my memory,' he says, 'like a claim of distant kinship affirmed in a supreme moment'. (HD, p. 119)

Each of these outlaws - Trejago, McIntosh, Kurtz - is treated as suspicious, at the least, by their own people, because they have gone beyond the pale, known and seen too much, ${ }^{9}$ and betrayed the public codes of their own kind. But each has also been responding to an acquisitive appetite for possession of something - knowledge of the other, power over the other - which is also an appetite of imperialism itself. Furthermore, in fact no one can accurately be reported as having really 'gone native', for that would mean becoming invisible to western eyes, whereas each of these transgressors is still recognisably different in appearance and status from the people they move among, and still connected to the home culture he seems to have renounced, and subject to its appeals. ${ }^{10}$ (Kurtz wants to be rich and famous in Europe and have kings meet him at railway-stations. Even McIntosh is dependent on the Kipling-narrator for decent tobacco and 'rational' conversation.) Though the lawman may condemn the outlaw, and the outlaw may despise the lawman, the relationship between them is closer than either might be willing to own up to: all that mutual insistence on the polar difference between them invites deconstruction as a symptom of a repressed suspicion of identity, a fear of discovering that they are not just interdependent, but interchangeable. They certainly tend to slide into each other, despite their best efforts to keep a distance.

To follow the relationship between outlaw and lawman now into the dynamics of J. M. Coetzee's Waiting for the Barbarians is to pass not only beyond the bounds of nineteenth-century realist representation but also through the postcolonial looking-glass, on the other side of which things are recognisable, but transposed and sometimes oddly distorted. In the first place, both the main male figures in Waiting for the Barbarians - the Magistrate and the policeman - are lawmen. But the Magistrate, already on the dangerous and tempting frontier, is the man who goes wrong from the perspective of the imperial metropolis and its emissary Colonel Joll. Years of service in a sleepy frontier town have made him tolerant and slack, 'sunk, after years in this backwater, in slothful native ways'. (WB, p. 50) ${ }^{11}$ To Joll and his men, the Magistrate's political and cultural loyalty is suspect, since he is closer to the frontier people than to the capital he has not seen since he was a young man, and closer still, at least in desire, to the barbarian woman he takes into his house, and later returns to her people. He speaks the frontier patois (though not the language of the barbarians), takes his sexual partners from among local people, has thirty years' experience of local life, and is in an amateur way a scholar of the region's historical past. He is a collector and a semiotician of the frontier, if not a very successful one, whether he is trying to decipher his archaeological finds, or the body of the alien woman he seeks but fails to explore. 'But with this woman it is as if there is no interior, only a surface across which I hunt back and forth seeking entry.' ( $W B$, p. 43 ) She is a sleeping dictionary in a script he cannot read.

For the Magistrate the borderland and the desert beyond is to be explored, for Colonel Joll it is to be policed. Joll is the fastidious metropolitan, who has been sent to lay down the law and clean up a potentially unstable frontier, and he finds the Magistrate's scruffy liberal regime an abject affront. In his view the Magistrate is a culture traitor: his 'treasonously consorting with the enemy' ( $W B$, p. 77 ) has criminally or madly endangered the very authority of the empire he is posted to the frontier to uphold. He has suffered the corruption of doubt. But officers of the 
Third Bureau have things cut and dried. Joll, at least at first, shows no curiosity at all about local people or conditions. He is a researcher too, in his way, but his researches are entirely instrumental and corroborative, his interrogations are not dialogic but catechistic: he knows what he wants to hear. No great reader, he writes in dust on the bodies of his captives the word ENEMY, and then gets his soldiers to beat it off. 'Enemy' was one of the words that exasperated Marlow; and more of that unseeing and reductive vocabulary is deployed when the Magistrate is told: 'The natives are at war with us.' (WB, pp. 77-8) From the repressive point of view of Joll and the empire, the Magistrate's lapse into native ways is more than an affront, it is an actual peril; for their version of colonial discourse, in the apt words of David Spurr, 'abjection consists not exactly in the condition of native life, but rather in the demoralizing crisis of going native, where the failure to mark the necessary bounds of exclusion is presented quite explicitly as filth and defilement'. ${ }^{12}$

If the Magistrate is promiscuous, Joll's attitude to 'native life' is paranoid: the empire must be protected from its deadly encroachment. Imposing emergency powers, but unable to profit from the local knowledge of the magistrate he despises and ignores, Joll proceeds to put into practice a policy that will create the very dangers he fears, and will eventually cause the forces of the empire to make a panic withdrawal from what had been a trouble-free frontier. But Joll's blinkered view would see, and will no doubt report, this disaster as the manager sees and will report the débâcle at the Inner Station - due to the indiscipline and cultural promiscuity of its representative, the central authority has had to retreat, and the district must remain closed to them for a while.

But although they are opposites, and soon become enemies, here too transgressor and lawman have more in common than either would like to admit. Each sees himself as a seeker after truth. They investigate one another, in an ominous circularity. Joll's tortures are a horrible travesty of the Magistrate's diggings, and of his stumbling attempts to know the barbarian girl. In Joll's eyes with their sinister glasses the Magistrate sees only his own doubled image cast back at him. His desperate resolve - 'I must assert my distance from Colonel Joll!' (WB, p. 44) - is a familiar attempt to conjure up a difference where he is starting to admit there may be a kinship.

This is a version of the recognition scene between outlaw and lawman and it is of interest that it identifies them both as, in a sense, rivals for possession of the barbarian girl. Much later, the magistrate spells it out. 'For I was not, as I liked to think, the indulgent pleasure-loving opposite of the cold rigid Colonel. I was the lie that Empire tells itself when times are easy, he the truth that Empire tells when harsh winds blow. Two sides of imperial rule, no more, no less.' (WB, p. 135) They are opposites only as two sides of a coin are opposite: but two sides of a coin must always face in two directions; and so Magistrate and policeman remain a closed book to each other. Joll needs the Magistrate's knowledge for just the same reason that he can never profit from it: because it has been acquired beyond the pale. So he interrogates the Magistrate about the meaning of the script painted on the wooden slips he has dug up from the ruins in the desert. The Magistrate 'reads' these characters as an allegory of the present situation of imperial oppression and discontent. But Joll is unable to make anything of the Magistrate's answers, interpreting them as simple insolence instead of as a warning he would do well to heed. After the catastrophe that befalls the expeditionary force sent out against the barbarians, as Joll and his soldiers scramble to abandon the town, the Magistrate has another bequest for him.

I have a lesson for him that I have long meditated. I mouth the words and watch him read them on my lips: 'The crime that is latent in us we must inflict upon ourselves,' I say. I nod and nod, driving the message home. 'Not on others,' I say: I repeat the words, 
pointing at my chest, pointing at his. He watches my lips, his thin lips move in imitation, or perhaps in derision, I do not know... (WB, p. 146-7)

The Magistrate peers through the glass of the carriage window and sees a face whose lips move in imitation of his own. It is another suggestively specular moment, recalling the earlier image of the Magistrate's face reflected in Joll's dark glasses, and again hinting at the kinship between the apostate and the orthodox. With Joll mimicking - or is it parodying? - the Magistrate's last words to him, both the fate and the meaning of this bequest are as ambiguous as the fate and the meaning of Kurtz's last words to Marlow, or McIntosh's forever unreadable book.

It seems the myth is still alive, with some new variations, in Coetzee's unspecific and haunting imperium. But arguably the greatest change, in the shift from a colonial to a postcolonial discourse, is the most obvious - the shift in perspective from the lawman to the outlaw: the myth is defamiliarized because in Coetzee's story it is the outlaw who narrates.

To recompose the myth into more easily recognizable shape it would have to be translated into the lawman's point of view; in which case it would look something like this. A figure of some prestige in the imperial culture, with a suspect interest in native ways and ensconced in an obscure and unvisited liminal space of empire, has succumbed to the (always feminised) temptations of native life, abandoned his ethnic prestige and his cultural identity, cast his lot in with the native people who seem to look up to him. Scornful or disobedient of his own lines of authority, allowing himself and his surroundings to go to the dogs, he is living in degradation and abjection from which he seems unwilling to be rescued and returned to right thinking and clean living. His apostasy has also threatened the imperial cause itself. A wellmeaning attempt to rescue him fails, but the man gone wrong leaves his would-be rescuer an enigmatic legacy, a message to take back to the metropolis.

This, the Joll version or inversion of the story of Waiting for the Barbarians, shows it running parallel to the two Kipling tales and to Heart of Darkness. In them, however, the lawman's narrative is a kind of sanctioned delivery of the transgressor's message. There may be a dialectic between the two, but ultimately the subversive words of transgression are contained in a discourse which is essentially that of the law and European order. But in Waiting for the Barbarians the story is not circumscribed by and processed through the lawman's gaze and memory. The means of narration are in the hands of the transgressor, however diffident and unsatisfactory a narrator he may be, however much 'a weak and wondering man who continually finds that words fail him'. ${ }^{13}$ Joll is expelled from the story, which then moves into a perilous postcolonial life of its own. And the Magistrate takes his place as a citizen of a town which is no longer a transgressive borderland (for the border has moved off, and the paradigm of law has shifted with it), but has now to face the future under a new jurisdiction, with whatever law it can devise for itself. His defining relations now must be not with Colonel Joll, but with some other. The stories of Trejago, McIntosh, and indeed Kurtz, were narrated in the past tense from the vantage of a present fenced off, however imperfectly, from the dangerous territory they had broached in going wrong. Waiting for the Barbarians tells its story in the present tense, and leaves its hero surviving into an unwritten future, where transgression will have to find a new meaning, since you cannot step across a boundary if the boundary is no longer there. 
${ }^{1}$ Page numbers in the text refer to Rudyard Kipling, Plain Tales from the Hills, ed. By H. R. Woudhuysen with an introduction and notes by David Trotter (London: Penguin Books, 1987), hereinafter PT.

${ }^{2}$ Ronald Hyman, Empire and Sexuality: The British Experience (Manchester and New York: Manchester University Press, 1990), p. 118. Kipling’s most memorable treatment of the tragic theme of the clandestine Indian mistress is in the tale 'Without benefit of clergy', first published in 1890, and collected in Life's Handicap.

${ }^{3}$ Gail Ching-liang Low, White Skins/Black Masks: Representation and Colonialism (London: Routledge, 1996), p. 260.

${ }^{4}$ Ibid., pp. 258-62.

${ }^{5}$ Page numbers in the text refer to Joseph Conrad, Youth: A Narrative, Heart of Darkness, The End of the Tether, Dent's Collected Edition (London: J. M. Dent and Sons, 1946-55), abbreviated to HD.

${ }^{6}$ John W. Griffith, Joseph Conrad and the Anthropological Dilemma: 'Bewildered Traveller' (Oxford, Clarendon Press, 1995), p. 150. Griffith is speaking mainly of the early Malayan novels, including Almayer's Folly, the first seven manuscript chapters of which Conrad carried with him during his Congo journey.

${ }^{7}$ Ibid., p. 145.

${ }^{8}$ John A. McClure, Kipling and Conrad: The Colonial Fiction (Cambridge, Mass.: Harvard University Press, 1981).

${ }^{9}$ Marlow, by contrast, is very careful not to see too much, declining to 'go ashore for a howl and a dance', (HD, p. 97) and refusing to hear about the ceremonies used when approaching Mr Kurtz. (HD, pp. 131-2)

${ }^{10}$ Conrad in England was himself rather a good example of the difficulty of giving a convincing performance of the 'native'. Kipling's Kim, at the beginning of his story, is pretty closely integrated into 'native ways', but this is an integration achieved without self-consciousness, effort, or indeed choice, by an unreflective child.

${ }^{11}$ J. M. Coetzee, Waiting for the Barbarians (London: Penguin Books, 1982), abbreviated to WB.

${ }^{12}$ David Spurr, The Rhetoric of Empire: colonial discourse in journalism, travel writing, and imperial administration (Durham, N. C.: Duke University Press, 1993), p. 84. 
${ }^{13}$ Susan VanZanten Gallaher, A Story of South Africa: J. M. Coetzee's Fiction in Context (Cambridge, Mass.: Harvard University Press, 1991), p. 121. 